\title{
PERFORMANCE EVALUATION OF BANKING SECTOR IN INDIAN CAPITAL MARKET: A COMPARATIVE STUDY
}

\begin{tabular}{|c|c|}
\hline Dr. KUSHALAPPA. & PRASANNA, \\
S, Senior Asst. Professor, Dept. of MBA, & $2^{\text {nd }}$ Year MBA, AIET, \\
AIET, Moodbidri & Mijar, Moodbidri. \\
\hline
\end{tabular}

\begin{abstract}
Banks are key financial intermediaries or institutions that serve as "middle man" in the transfer of fund from servers to those who invest in real assets as house, equipment and factories. In performing this function financial intermediaries improve the well being of both saver and investor. By improving economic efficiency they raise living standard of the society. The banking sector is considered to be an important source of financing for most businesses. They play a very important role in the effort to attain stable prices, high level of employment and sound economic growth. They make funds available to meet the needs of individuals, businesses and the government. In doing this, they facilitate the flow of goods and services and the activities of governments. Banking sector plays an important role in the Indian Capital Market. Due to ever increasing demand for banking products in India, banking industry plays a significant role in the growth and development of Indian Capital Market. The current study is an attempt to compare the performance of private sector banks with the performance of public sector banks in Indian Capital Market. The sample is selected from the banks listed in BSE. The study period is One year from $1^{\text {st }}$ April, 2013 to $31^{\text {st }}$ March, 2014.
\end{abstract}

KEY WORDS: Banks, capital market, performance, returns.

\section{INTRODUCTION}

Banking sector is the most prominent sector of the financial system in India. Remarkable progress has been made with respect to the banking sector in the post liberalization period. The financial health of the commercial banks has improved manifolds with respect to capital adequacy, profitability, and asset quality and risk management. Further, deregulation has opened new opportunities for banks to increase revenue by diversifying into investment banking, insurance, credit cards, depository services, mortgage, securitization, etc. Liberalization has created a more competitive environment in the banking sector. Banking has helped in developing the vital sectors of the economy.It has translated the hopes and aspirations of millions of people into reality. Today, Indian banks have developed to such an extent that, they can confidently compete with modern banks of the world. Banks are key financial intermediaries or institutions that serve as "middle man" in the transfer of fund from servers to those who invest in real assets as house, equipment and factories. In performing this function financial intermediaries improve the well being of both saver and investor.

By improving economic efficiency they raise living standard of the society. The banking sector is considered to be an 
important source of financing for most businesses. They play a very important role in the effort to attain stable prices, high level of employment and sound economic growth. They make funds available to meet the needs of individuals, businesses and the government. In doing this, they facilitate the flow of goods and services and the activities of governments. Banking sector plays an important role in the Indian Capital Market. Due to ever increasing demand for banking products in India, banking industry plays a significant role in the growth and development of Indian Capital Market. The current study is an attempt to compare the performance of private sector banks with the performance of public sector banks in Indian Capital Market. The sample is selected from the banks listed in BSE. The study period is One year from $1^{\text {st }}$ April, 2013 to $31^{\text {st }}$ March, 2014.

\section{OBJECTIVES}

The core objective of this study is to compare the performance of public sectors banks with private sector banks in Indian Capital Market. However, in order to achieve the main objective, the following specific objectives have been framed:

$>$ To make a comparison between the performance of public sector banks under study

$>$ To compare the performance of private sector banks under study
To rank the banks under risk and returns

To offer meaningful suggestions to the investors based on the findings of the study.

\section{METHODOLOGY:}

The study is purely based on secondary data collected from various sources like, books and websites. The sample size is 20 . It includes 10 public sector banks and 10 private sector banks. Under each sector, the sample is selected randomly. The monthly share prices have been collected for each of the bank under study from February, 2013 to April, 2014. This data is used to calculate actual return, CAPM return and abnormal return of each of the 20 banks.

\section{DATA ANALYSIS AND INTERPRETATION}

This part of the study deals with the analysis of data collected for the study. 
Asia Pacific Journals

Table 1: Ranking of public sector banks on the basis of risk and returns

\begin{tabular}{|r|r|r|r|r|r|r|r|r|r|r|}
\hline \multicolumn{1}{|c|}{ M/B } & \multicolumn{1}{|c|}{ BOB } & \multicolumn{1}{c|}{ SBI } & \multicolumn{1}{c|}{ Sy B } & \multicolumn{1}{c|}{ BOI } & \multicolumn{1}{c|}{ UBI } & Co. B & \multicolumn{1}{l}{ BOM } & \multicolumn{1}{c|}{ IOB } & Dena & Canara \\
\hline Average & 1.44 & -0.13 & -0.29 & -0.67 & -2.35 & -2.25 & -1.27 & -1.75 & -2.52 & -2.33 \\
\hline Rank & 1 & 2 & 3 & 4 & 9 & 7 & 5 & 6 & 10 & 8 \\
\hline SD & 15.45 & 11.56 & 15.00 & 20.04 & 17.83 & 11.69 & 13.61 & 10.30 & 13.80 & 16.40 \\
\hline CV $(\%)$ & 1071.05 & 9126.35 & 5232.41 & 2984.36 & 758.54 & 519.75 & 1072.28 & 587.39 & 548.15 & 702.99 \\
\hline Rank & 6 & 10 & 9 & 8 & 5 & 1 & 7 & 3 & 2 & 4 \\
\hline
\end{tabular}

\section{Source: Authors Compilation}

Table 1 show the fact that Bank of Baroda has highest actual returns and Dena Bank has lowest returns compared to other banks under study. Except Bank of Baroda, all other banks have earned negative returns during the period of study. From the risk point of view, Corporation bank has lowest riskand State Bank of India has highest risk.

Table 2: Ranking of private sector banks on the basis of risk and returns

\begin{tabular}{|r|c|c|c|c|c|c|c|c|c|c|}
\hline \multicolumn{1}{|c|}{ M/B } & HDFC & Axis & ICICI & Kotak & Yes.B & ING & Indus & Dn. L & Fedral & Laxmi.VI \\
\hline Average & 1.77 & 2.03 & 2.14 & 1.80 & 1.50 & 1.94 & 2.32 & -1.23 & -8.32 & -1.04 \\
\hline Rank & 6 & 3 & 2 & 5 & 7 & 4 & 1 & 9 & 10 & 8 \\
\hline SD & 7.35 & 15.72 & 12.86 & 8.27 & 20.14 & 12.40 & 13.14 & 16.89 & 23.54 & 9.59 \\
\hline CV(\%) & 415.13 & 775.44 & 600.47 & 458.43 & 1342.22 & 637.71 & 566.45 & 1373.55 & 282.88 & 919.38 \\
\hline Rank & 2 & 7 & 5 & 3 & 9 & 6 & 4 & 10 & 1 & 8 \\
\hline
\end{tabular}

Source: Authors Compilation

It is clear from Table 2 that Indus IndBank has highest average actual returns and

Federal Bank has lowest average actual returns. In terms of risk, Fedral bank ranked first and Dhanlakshmi bank has obtained the last rank. Out of ten banks, only three banks have negative returns during the study period.

Table 3: Ranking of banks under study, on the basis of actual returns

\begin{tabular}{|r|l|c|c|}
\hline Sl.no & \multicolumn{1}{|c|}{ Banks } & Avg returns & Ranks \\
\hline 1 & Indusind Bank & 2.32 & 1 \\
\hline 2 & Axis Bank & 2.03 & 2 \\
\hline 3 & ICICI & 2.03 & 3 \\
\hline 4 & ING. Vyshya & 1.94 & 4 \\
\hline 5 & Kotak Mahindra Bank & 1.8 & 5 \\
\hline 6 & HDFC & 1.77 & 7 \\
\hline 7 & Yes Bank & 1.5 & 6 \\
\hline
\end{tabular}


Asia Pacific Journals

\begin{tabular}{|c|c|c|c|}
\hline 8 & Bank of Baroda & 1.44 & 8 \\
\hline 9 & State Bank of India & -0.13 & 9 \\
\hline 10 & Syndicate Bank & -0.29 & 10 \\
\hline 11 & Bank of India & -0.67 & 11 \\
\hline 12 & Lakshmi Vilas bank & -1.04 & 12 \\
\hline 13 & Dhanalakhsmi Bank & -1.23 & 13 \\
\hline 14 & Bank of Maharastra & -1.27 & 14 \\
\hline 15 & Indian Overseas Bank & -1.75 & 15 \\
\hline 16 & Corpoartion Bank & -2.25 & 16 \\
\hline 17 & Canara Bank & -2.33 & 17 \\
\hline 18 & Union Bank of India & -2.35 & 18 \\
\hline 19 & Dena Bank & -2.52 & 19 \\
\hline 20 & Fedral Bank & -8.32 & 20 \\
\hline
\end{tabular}

\section{Source: Authors Compilation}

Table 3 show the fact that out of twenty banks under study, Indusind Bank has obtained the first rank in terms of average actual returns and it is followed by Axis Bank, ICICI, ING Vyshya Bank, Kotak
Mahindra Bank, HDFC Bank and Yes Bank. The top seven banks in terms of actual returns are the private sector banks. Similarly, Fedaral Bank, a private sector bank has earned the lowest return among the twenty banks under study.

Table 4: Ranking of banks under study, on the basis of CAPM returns

\begin{tabular}{|l|l|c|c|}
\hline Sl.no & \multicolumn{1}{|c|}{ Banks } & CAPM Returns & Rank \\
\hline 1 & Axis Bank & 2.69499 & 1 \\
\hline 2 & Ing.vysya & 2.178424 & 2 \\
\hline 3 & Kotak Mahindra Bank & 1.20304 & 3 \\
\hline 4 & ICICI & 1.04955 & 4 \\
\hline 5 & HDFC & 0.963223 & 6 \\
\hline 6 & Yes Bank & 0.110704 & 7 \\
\hline 7 & Indusind Bank & -0.08443 & 9 \\
\hline 8 & Corporation Bank & -0.32882 & 10 \\
\hline 9 & Canara Bank & -0.36355 & 11 \\
\hline 10 & Union bank of india & -0.37009 & 12 \\
\hline 11 & Bank of Maharastra & -0.38525 & 13 \\
\hline 12 & Syndicate bank & -0.54098 & -0.58459 \\
\hline 13 & State bank of india & & 5 \\
\hline
\end{tabular}


Asia Pacific Journals

\begin{tabular}{|c|l|c|c|}
\hline 14 & Bank of India & -0.65204 & 14 \\
\hline 15 & Lakshmi.vilas & -0.71835 & 15 \\
\hline 16 & Dena Bank & -1.12299 & 16 \\
\hline 17 & Bank of Baroda & -1.41247 & 17 \\
\hline 18 & Dhanlakshmi Bank & -1.75853 & 18 \\
\hline 19 & Indian Overseas Bank & -1.94965 & 20 \\
\hline 20 & Fedral Bank & -8.97919 & 19 \\
\hline
\end{tabular}

\section{Source: Authors Compilation}

Table 4 shows that expected returns from Axis bank is the highest and it is followed by ING. Vyshya, Kotak Mahindra Bank, ICICI, HDFC, Yes Bank, Indusind Bank and then Corporation Bank. Therefore it is clear that the expected returns from private sector banks are higher than the expected returns from the public sector banks.

Table 5: Ranking of banking securities on the basis of risk

\begin{tabular}{|r|l|c|c|}
\hline \multicolumn{1}{|c|}{ Sl.no } & \multicolumn{1}{|c|}{ Banks } & Coefficient of Variance & Rank \\
\hline 1 & Fedral & 282.88 & 1 \\
\hline 2 & HDFC & 415.13 & 2 \\
\hline 3 & Kotak Mahindra & 558.43 & 3 \\
\hline 4 & Corporaration bank & 548.15 & 5 \\
\hline 5 & Dena & 566.45 & 6 \\
\hline 6 & Indus ind & 587.39 & 7 \\
\hline 7 & Indian overseas & 600.47 & 8 \\
\hline 8 & ICICI & 637.71 & 9 \\
\hline 9 & Ing.vysya & 702.99 & 10 \\
\hline 10 & Canara & 758.54 & 11 \\
\hline 11 & Union bank of india & 775.44 & 12 \\
\hline 12 & Axis & 919.38 & 13 \\
\hline 13 & Lakshmi.vilas & 1071.05 & 15 \\
\hline 14 & Bank of baroda & 1072.28 & 16 \\
\hline 15 & Bank of maharstra & 1342.22 & 17 \\
\hline 16 & Yes bank & 1373.55 & 19 \\
\hline 17 & Dhanlakshmi & 2984.36 & 20 \\
\hline 18 & Bank of india & 5232.41 & \\
\hline 19 & Syndicate Bank & 9126.35 & \\
\hline 20 & State bank of india & & 18 \\
\hline & & & 14 \\
\hline
\end{tabular}




\section{Source: Authors Compilation}

It is clear from Table 5 that Fedaral Bank has the lowest coefficient of variance, followed by HDFC, Kotak Mahindra, Corporation Bank, Dena Bank, Indusind bank and so on. State Bank of India has highest variance in the returns of its stocks.

\section{FINDINGS AND CONCLUSION}

- It is found in the study that among the public sector banks, Bank of Baroda has highest actual returns and Dena Bank has lowest returns. Except Bank of Baroda, all other banks have negative returns during the period of study.

- As it is clear from the study that from risk point of view, Corporation bank has lowest risk and State Bank of India has highest risk.

- It is clear from the study that among the private sector banks, Indusind Bank has highest average actual returns and Federal Bank has lowest average actual returns.

- It is fact from the study thatFedral bank is the least risky security and Dhanlakshmi bank is the most risky private sector security.

- It is found from the study that among the various public and private sector banks, Indusind Bank has earned highest actual average returns and it is followed by Axis Bank, ICICI, ING Vyshya
Bank, Kotak Mahindra Bank, HDFC Bank and Yes Bank. The top seven banks in terms of actual returns are the private sector banks. Similarly, Fedaral Bank, a private sector bank has earned the lowest returns.

- It is crystal clear from the study that the expected returns from Axis bank are the highest and it is followed by ING. Vyshya, Kotak Mahindra Bank, ICICI, HDFC, Yes Bank, Indusind Bank and then Corporation Bank. Therefore it is clear that investors' expectation from private sector banks is higher than the public sector banks.

- It is fact from the study that even at abnormal returns, private sector banks have dominated the public sector banks

Finally, it can be concluded that the performance of private sectors banks is better than the performance of public sector banks. Seventy percent of the private sector banks have earned positive returns during the study period, whereas, only one bank out of 10 public sector banks have earned positive returns. One of the interesting findings of the study is that the investors expect more returns from private sector banks than from public sector banks. It would be because of the reason that it is private bank which 
is not so secured like a public sector bank. The study highlights the fact that during study period, compared to the public sector banks, most of the private sector banks have performed extremely well.

\section{BIBLIOGRAPHY}

- Avadhani V.A.(2011), Security Analysis and Portfolio Management, Himalaya Publishing House.

- Balla V. K. (2002), Portfolio Analysis and Management, Sulthan Chand and Co. Ltd., New Delhi.

- Booie.Zvi, Kane Alex and et.al.(2006), Investments, $6^{\text {th }}$ edition, Tata McGraw Hill, New Delhi.

- Chandra Prasanna (2008), Investment Analysis and Portfolio Management, $3^{\text {rd }}$ edition, Tata McGraw Hill, New Dehi.

- Fisher. E. Donald and Jordan. J. Ronald (2006), Security Analysis and Portfolio Management, Pearson Prentice Hall.

- Kevin. S (2008), Portfolio Management, $2^{\text {rd }}$ edition, PHI Learning Pvt. Ltd, New Delhi. 